IZA DP No. 6442

The Demand for, and Consequences of, Formalization among Informal Firms in Sri Lanka

Suresh de Mel

David McKenzie

Christopher Woodruff

March 2012 


\title{
The Demand for, and Consequences of, Formalization among Informal Firms in Sri Lanka
}

\author{
Suresh de Mel \\ University of Peradeniya
}

David McKenzie

World Bank

and IZA

\author{
Christopher Woodruff \\ University of Warwick \\ and IZA
}

Discussion Paper No. 6442

March 2012

\author{
IZA \\ P.O. Box 7240 \\ 53072 Bonn \\ Germany \\ Phone: +49-228-3894-0 \\ Fax: +49-228-3894-180 \\ E-mail: iza@iza.org
}

\begin{abstract}
Any opinions expressed here are those of the author(s) and not those of IZA. Research published in this series may include views on policy, but the institute itself takes no institutional policy positions.

The Institute for the Study of Labor (IZA) in Bonn is a local and virtual international research center and a place of communication between science, politics and business. IZA is an independent nonprofit organization supported by Deutsche Post Foundation. The center is associated with the University of Bonn and offers a stimulating research environment through its international network, workshops and conferences, data service, project support, research visits and doctoral program. IZA engages in (i) original and internationally competitive research in all fields of labor economics, (ii) development of policy concepts, and (iii) dissemination of research results and concepts to the interested public.
\end{abstract}

IZA Discussion Papers often represent preliminary work and are circulated to encourage discussion. Citation of such a paper should account for its provisional character. A revised version may be available directly from the author. 


\section{ABSTRACT \\ The Demand for, and Consequences of, Formalization among Informal Firms in Sri Lanka*}

The majority of firms in most developing countries are informal. We conducted a field experiment in Sri Lanka which provided incentives for informal firms to formalize. Offering only information about the registration process and reimbursement for direct registration costs had no impact on formalization. Adding payments equivalent to one-half to one month's profits for the median firm leads to registration of around one-fifth of firms. A larger payment equivalent to two month's median profits induces half of the firms to register. Among the firms not registering after being offered this larger incentive, many faced issues related to ownership of land. Three follow-up surveys at 15 to 31 months after the intervention measure the impact formalizing has on these firms. Although mean profits increase, this appears largely due to the experiences of a few firms which grew rapidly, with most firms experiencing no increase in income as a result of formalizing. We also find little evidence for most of the channels through which formalization is hypothesized to benefit firms, although formalized firms do advertise more. Finally, formalizing is found to result in a large increase in trust in the state.

JEL Classification: O17, O12, C93, D21, L26

Keywords: informality, small enterprises, entrepreneurship

Corresponding author:

David McKenzie

The World Bank

MSN MC3-307

1818 H Street N.W.

Washington, DC 20433

USA

E-mail: dmckenzie@worldbank.org

\footnotetext{
* We thank the World Bank, the Knowledge for Change Program Trust Fund, DFID, and the Ewing Marion Kauffman Foundation for funding for this project. We thank Bill Maloney, Dina Pomeranz, Russell Toth, and seminar participants at Cambridge, LSE, the NBER summer institute, UC Berkeley, the University of Washington-St Louis, and the World Bank for helpful comments. All opinions offered represent those of the authors alone, and do not necessarily reflect the views of the World Bank, its Executive Directors, or the countries they represent.
} 


\section{Introduction}

The majority of firms in most developing countries are informal. In Sri Lanka, for example, only one-fifth of firms operating without paid workers are registered with any government agency. Even among firms employing paid workers, the majority are unregistered with one or more pertinent agencies. Policymakers are concerned about high levels of informality for two reasons. First, informality is associated with lower tax collection, restricting the government's ability to finance public services (Levy 2008). Second, the coexistence of formal and informal firms means that firms competing in the same industry face different marginal production costs (e.g., labor costs and taxes), leading to an inefficient allocation of resources in the economy (Hsieh and Klenow 2009; Levy 2008). How can informal firms be induced to formalize?

A firm's decision to become formal depends on the costs and benefits of formality. There are two prevailing views of informality, dubbed by Perry et al. (2007) as exclusion and exit. The exclusion view focuses on the costs of registering. This view is most notably associated with the work of de Soto (1989), who argued that burdensome entry regulations prevent small firms from becoming formal. These firms suffer a loss in productivity as a result of remaining informal. The natural policy response is then to remove the burdensome regulations. Spurred in part by the World Bank/IFC Doing Business project, governments around the world have in recent years streamlined the process of becoming formal. Indeed, since 2004, 75 percent of the countries included in the Doing Business survey have adopted at least one reform making it easier to register a business (IFC, 2009).

But is streamlining the registration process sufficient to spur formality? The exit view focuses more attention on the balance between the costs and benefits of formality. The decision to become formal is comparable to any other investment decision taken by the firm. Each firm compares its perceived costs of being formal - including both initial registration and ongoing costs (e.g., tax payments) — with its perceived benefits of being formal (e.g., access to banks and courts and to government contracts). More able firm owners with larger efficient scales rationally become formal as they grow large enough to benefit from the formal institutions of civil society. Smaller, less productive, firms do not find formality desirable because they receive no benefit from access these formal institutions (Maloney, 2004).

We conduct a field experiment in Sri Lanka which reduces the information costs and increases the monetary benefits of formalizing in order to measure the latent demand for formalization, and the consequences that formalizing has on informal firms. We divided a sample of informal firms with 1 to 14 paid employees into four treatment groups and a control group. The first treatment group was given information about the costs and benefits of, and procedures for, registering their firm at the division level with the Divisional Secretariat (DS) - the relevant registration for tax purposes. Additionally, they were reimbursed for the (modest) direct cost of registration if they registered. The second, third, and fourth 
treatment groups were provided the same information and also offered a payment of 10,000 Sri Lankan Rupees (LKR), 20,000 LKR and 40,000 LKR (approximately US\$88, \$175 and \$350 respectively) to register.

We find that providing information and reimbursing the cost of registration does not induce firms to register. In contrast, 17-22 percent of eligible firms register when offered 10,000 or 20,000 LKR, just under half a month's and one month's profits for the median firm respectively, and 48 percent register when offered 40,000 LKR. Few of those who didn't register when offered 40,000 LKR registered when given additional time or when offered 80,000 LKR. The experiment sheds light not only on the demand for informality, but also on the nature of barriers to formal registration. An important share of the firms not registering after receiving the largest incentive report that issues related to land tenancy prevented them from doing so. These firms operated with informal leases or agreements-ironically, often on government-owned land-and hence were unable to provide authorities with the required proof of ownership of the land on which the firm operated.

Three follow-up surveys of these same firms were conducted at 15, 22 and 31 months after the intervention, enabling us to examine whether and how the firms benefited from formalization. Firms which formalized are found to have higher profits, although this impact seems largely due to the experiences of a few firms experiencing substantial growth, with the distribution of profits almost identical for treatment and control firms over most of the distribution. Examining the channels through which formalization might benefit firms, we find increased advertising and use of receipt books, but no increases in receipt of government contracts, use of bank accounts or loans, or participation in government programs. Consistent with the effect of formal land titling reported in Di Tella et al (2007), we also find impacts in terms of attitudes: firms that formalize are more likely to trust local government and agree that paying taxes is a civic duty, but are also more likely to agree that small businesses are taxed too much.

This study is the first to experimentally induce informal firms to register for tax purposes. ${ }^{1}$ It builds on an existing literature which has largely focused on the impacts of entry regulations at both the macro and micro levels, and on new firm creation, rather than formalization of existing informal firms. At a cross country level, countries with more burdensome entry regulations have larger informal sectors (Djankov et al, 2002) and costly entry regulations are also associated with the creation of fewer limited

\footnotetext{
${ }^{1}$ An unpublished study that took place over a similar time frame to our experiment by Alcázar et al. (2010) in Lima, Peru also tries to formalize firms through subsidizing the costs of registration, although they focus on municipal level registration. Whilst their study has very high attrition levels (over half their sample attrits), the preliminary results we have seen suggest the results of our study may generalize to other contexts. We discuss this study in more detail in Section 6.
} 
liability companies (Klapper et al, 2006). ${ }^{2}$ But the endogeneity of regulatory choices complicates any claim of causation based on the cross country patterns. Several micro studies have therefore examined the impact of regulatory reforms. Bruhn (2011) and Kaplan et al. (2011) study a reform in Mexico which reduced the time required to register at the municipal level from 30 to 2 days for firms operating in specified sectors. Both find some increase in the number of formal firms, although Bruhn concludes this increase is largely coming from new entry rather than formalization of existing firms, while Kaplan et al use different data to reach the opposite conclusion. Fajnzylber et al. (2011) analyze a simplification program in Brazil and find that the firms which open just after a reform are larger and more likely to operate in a permanent location - a finding which they interpret as evidence that formalization improves firm performance, but which could also be the result of selection into firm entry. ${ }^{3}$ Monteiro and Assunção (2011) examine the same reform and find that new retail firms created after the reform were more likely to be formal than firms in sectors not affected by the reform. Finally, in one of the few published studies to examine the impact of formalizing on existing informal firms, McKenzie and Sakho (2010) use distance to the registration office as an instrument for registration costs, and find that some firms in Bolivia facing high costs of formalizing would gain on net from registering for taxes, but that other firms would lose from doing so and so appear to be rationally informal.

The remainder of the paper is set out as follows. Section 2 describes the process of becoming formal as a small firm in Sri Lanka, and gives evidence as to the extent of formality by firm size. Section 3 describes our intervention, Section 4 the results on the demand for formalizing, and Section 5 the consequences of formalizing. Section 6 discusses the extent to which these results may generalize, and Section 7 concludes.

\section{Becoming Formal in Sri Lanka}

The process of registering a business in Sri Lanka is similar to that in many other developing countries, with multiple levels of registration. Two levels are required of all firms, regardless of size. First, firms are required to obtain a license at the municipal level. Depending on whether the firm is located in a rural, urban, or semi-urban area, this implies registration with the Pradeshiya Saba, Municipal Council or Urban Council (P.S. or UCMC). In some sectors, obtaining this license requires a site visit

\footnotetext{
${ }^{2}$ There is also firm-level evidence for an impact of entry regulations. Bertrand and Kramarz (2002) find that entry regulations are associated with significantly slower employment growth among French retail firms.

${ }^{3}$ An unpublished study that took place over a similar time frame to our experiment by Alcázar et al. (2010) in Lima, Peru also tries to formalize firms through subsidizing the costs of registration, although they focus on municipal level registration. Whilst their study has very high attrition levels (over half their sample attrits), the preliminary results we have seen suggest the results of our study may generalize to other contexts. We discuss this study in more detail in Section 6.
} 
from a revenue officer and/or a public health inspector, or approval by a police officer and the municipal chairman. Firms must also pay an annual license fee which depends on the sector, but typically ranges from 500 to 5000 LKR. The main benefit is being able to operate without fear of being harassed by local officials, who typically monitor the most visible enterprises since these license fees are an important local revenue source.

Second, all firms must register at the division level with the Divisional Secretariat. ${ }^{4}$ The one-time registration with the DS establishes the business as a legal entity for tax purposes and provides the business with a Business Registration Certificate (BRC). The BRC serves as legal proof of the enterprise's existence and is needed, for instance, for the firm to be able to sell to government institutions and to larger firms which require formal transaction receipts. The BRC is also needed to open a bank account in the name of the business, and to obtain a loan from most commercial banks. Registration at the DS Division level involves payment of a modest fee, but does not by itself imply the firm is liable for taxes. Taxes need to be paid only if annual net profits are in excess of 300,000 LKR, and theoretically, are payable regardless of the registration status of the firm. In practice, registration makes the firm more visible to tax authorities, and hence increases the expected tax payments for firms with incomes exceeding this threshold.

Appendix 1 provides details on the actual process experienced by firms registering with the DS during our experiment. The process was easier in Colombo, where firm owners were generally not asked to provide any documents other than their national identity card, and could choose to pay $1000 \mathrm{LKR}$ instead of 500 LKR for express service and get their BRC in one day. For the firms in our study the registration process typically involved a total of 2 days and 2 visits to the In contrast, firms in Kandy were required to also provide proof of business existence, proof of municipal registration, and a letter of no objection from the property owner. The median firm spent three days getting these other documents processed, and waited 6 days after submitting all documents until they received the BRC.

Larger firms are subject to two additional registrations. Firms with paid workers are required to register these workers with the Ministry of Labour for the Government Social Security Schemes: the Employee's Provident Fund (EPF) and the Employee's Trust Fund (ETF). EPF consists of a monthly payment of 20 percent of the employee's earnings (consisting of a 12\% employer contribution and an $8 \%$ employee contribution), and ETF a further 3\% employer contribution. Formal employers with more than

\footnotetext{
${ }^{4}$ There are four administrative levels in Sri Lanka: Provinces (9), Districts (25), Divisions (324), and Grama Nilidaris (GNs, 14,008). Political councils are elected at both the Provincial and local levels. The local councils are called by different names depending on the area they cover, with Municipal Councils in the 18 largest urban areas, Urban Councils in a further 42 urban/semi-urban areas, and Pradeshiya Sabhas in rural areas. Rural Sri Lanka is divided into 270 Pradeshiya Sabhas. Registration of enterprises thus takes place both at the local and district level.
} 
14 workers also face high severance pay costs if they lay workers off. Finally, firms with revenues exceeding 500,000 LKR per quarter or 1.8 million LKR per year must also register for VAT. The VAT tax rate is $20 \%$ of value-added for most goods, with producers of some goods paying a lower $10 \%$ rate and others exempt entirely.

\subsection{Formality Levels in Practice}

Figure 1 summarizes the percentage of firms which reported being registered with each of the four Government entities according to the number of paid employees in the firm. The data come from the baseline of the Sri Lanka Longitudinal Survey of Enterprises (SLLSE), collected by the authors between January and May 2008. The survey contains 2865 enterprises, and is representative of enterprises in the 31 largest cities and towns (outside the Northern province which was inaccessible due to civil conflict). A door-to-door listing exercise of households was carried out, to ensure the survey was able to detect both formal and informal firms. The vast majority of enterprises have zero paid workers, and we see that only 23 percent of these non-employers are registered at the local (P.S. / UCMC) level and only 20 percent are registered at the DS Division level. Less than 1 percent of the non-employers report being registered for VAT. Registration at all four levels rises quickly with firm size, so that 75 percent of those with 5 paid employees are registered with the P.S. or UCMC and 68 percent with the DS. However, the percent registered then appears to plateau, with approximately 70 to 80 percent registered with the DS for firms with 6 to 20 employees. There are fewer firms in the SLLSE sample as the number of paid workers grows, making the point estimates more variable at larger firm sizes. Registration of at least some of the workers of the firm with EPF/ETF is less common in firms with fewer than 5 workers, but also increases rapidly with firm size so that 87 percent firms with 10 employees have registered at least some of their workers. VAT registration is the least common, but also grows with firm size, so that about half of firms with 10 or more workers are registered for VAT.

Among those firms with 1 to 10 paid workers which were not registered with any of the four Government entities, only 23 percent said they had ever considered registering their business; the majority of the remainder said they felt their businesses were too small to have to register. There is often a presumption that the informal sector faces a high level of de facto fees in terms of fines, penalties and bribes which arise from operating without a license. However, this does not appear to be the case in Sri Lanka: fewer than 0.5 percent of unregistered firms with 1 to 10 paid workers reported paying a fine, penalty or bribe in the last year because of their unregistered status. Indeed, most informal firms report having little interaction with officials at all: only 5 percent reported receiving a visit from a Pradeshiya Saba official, 2 percent from a DS official, and 1 percent from a tax official in the past year.

\subsection{Focusing on DS registration}


Figure 1 shows that registration at all levels increases markedly with the number of employees. While most firms with 1 or 2 workers are entirely unregistered, a majority of firms with 10 or more workers are registered with each of the relevant agencies. Our goal is to understand the demand for formality among firms in this size range. We focus on one particular dimension of formalizing, registering with the DS. This DS registration most closely corresponds to the concept of formalizing underlying much of the discussion of formalization in the literature, because it establishes a legal and tax presence, and is the prerequisite for selling to the government and other firms which require registration, as well as for applying for most bank loans.

\section{The Experiment}

\subsection{Selection of the Sample}

We chose to carry out our study in the two largest cities in Sri Lanka-Colombo and Kandy. Since the goal of our intervention is to gauge the demand for formality among informal firms, we needed to construct a sample of firms not registered with the DS at the time of the baseline survey. There was no existing sample frame which could be used for this, so we carried out our own screening exercise. ${ }^{5} \mathrm{We}$ randomly selected 5 Divisional Secretariat Divisions in each city. In December 2008, we had research assistants go door-to-door in these areas to screen firms, with the goal of surveying approximately 50 unregistered firms in each selected DS. Firms were selected for the baseline survey if they were not registered with the DS, were not in seasonal agriculture or fisheries, had 1 to 14 paid employees, and had an owner aged 20 to 55 who worked at least 20 hours in the enterprise each week. Few firms of this size are owned by women, and so we chose to restrict the sample to male owners and to businesses jointly owned by a husband and wife. A sixth DS Division was added in Kandy due to difficulty finding enough informal firms which satisfied these criteria - there are lots of informal firms without paid workers, but fewer with paid workers.

An obvious concern in attempting to construct a sample of the unregistered is whether firms will reveal that they are not registered (and hence that they are breaking the law). We used university students to carry out the surveying, and they presented firm owners with a letter on University of Peradeniya letterhead emphasizing that this was a research study. In an environment where informality is commonplace among smaller firms we believe that most unregistered firms did tell the truth. Indeed, as we will discuss in more detail, our sample contains a non-trivial fraction of firms which were "quasiregistered", but who answered that they were not registered, suggesting that there were not strong incentives for firms to pretend to be registered.

\footnotetext{
${ }^{5}$ We decided against using the sample from our previous survey, the SLLSE, since logistically it was infeasible for us to implement the experiment island-wide, and there were too few firms in the SLLSE that were in Kandy and Colombo and which were not part of a separate experiment.
} 
The resulting baseline sample consists of 520 firms, evenly split between Colombo and Kandy. Although our screening criteria allowed firms to have up to 14 paid employees, there are more firms in general with 1-5 employees than with 6-14, and a larger percentage of the smaller firms are informal. As a result, 90 percent of the baseline sample has 5 or fewer paid employees, with a median of 3 paid employees. Although all of the firms said they were not registered with the DS, 68 percent reported being registered with the municipal council or Pradeshiya Saba, so they are only partially informal. However, only 5 percent have any of their workers registered with EPF/ETF. The firms cover a range of industries, with 44 percent in services (e.g. motor vehicle repair, restaurants), 32 percent in manufacturing (e.g. manufacturing fabricated metal products and glass products) and 23 percent in retail. Mean (median) monthly profit for the firms in our sample was 33,886 LKR (25,000 LKR), approximately US\$300 (220) at market exchange rates at the time of the survey, with a 10-90 percentile range of 9000-75000 LKR (US\$79-658). The median firm had been in business for 6 years, with 80 percent of the firms being more than three years old. Most of the businesses were standalone enterprises, with only 8 percent located inside the home.

\subsection{Why do firms see as the costs and benefits of formalizing?}

Firm owners were asked open-ended questions about the possible costs and benefits of registering with the DS. The most common perceived cost or disadvantage was having to pay taxes and being more likely to be visited by tax authorities, mentioned by 46 percent of the owners. The next most common concern, mentioned by 37 percent of the owners, was that the process of registration was too burdensome or too time consuming. A third common concern was that DS registration would require the firm to pay EPF/ETF, or subject the firm to a greater risk of being visited by labor inspectors, which was mentioned by 24 percent of owners. ${ }^{6}$ Only 13 percent believed the initial cost of registration was high.

With regard to the benefits of registration, more than half of the owners (58 percent) mentioned being able to get a bank account in the business name or apply for a bank loan. The second most common response to this question (23 percent of owners) was that there is no particular advantage of registering with the DS. Approximately 10 to 15 percent of firms mentioned a number of other advantages, such as being able to operate on a larger and more visible scale, qualifying for participation in government programs, being able to sell to the government and firms that require registration, and having a lower risk of being fined. As with the nationwide sample, less than 1 percent reported actually having had to pay any fines or bribes in the last year for operating informally, so the risk of being fined is already low.

\footnotetext{
${ }^{6}$ We note that this perception is not accurate- the ETF/EPF registration is separate and there is no formal communication between the two agencies.
} 
These responses suggest that firms have at least somewhat accurate information about some of the advantages and disadvantages of registering. They have much less knowledge of the specifics of how to register. Only 17 percent knew the correct cost of registering at the DS. The most common response when asked how long it takes to register-given by 22 percent of the owners-was "don't know". The next most common responses were 30 days, 60 days, and 90 days. Firms also lacked knowledge of their income tax responsibilities. Firm owners were asked how much a business owner would have to pay as income tax if their annual income was 100,000 LKR. Only 2 percent got the correct answer of zero, with 55 percent saying "don't know." The median answer amongst those professing to know was 2,000 LKR. When asked the same question with respect to an annual income of 400,000 LKR, again 50 percent said they didn't know, and 88 percent of those answering with a number gave an answer higher than the true rate of 3,400 LKR, with the median answer 8000 LKR.

Finally, firm owners were asked in the baseline a hypothetical question of whether they would register with the DS if someone would pay the fixed cost of registration. 61 percent of firm owners answered yes to this question, suggesting some willingness to formalize if the costs were reduced.

\subsection{The Intervention}

The baseline survey and hypothetical questions suggest that the informal firms are not perfectly informed about the process of registration or its costs and benefits, and that many express a willingness to register if someone pays the upfront costs. We therefore designed an intervention which provided information about the costs, benefits, and process of registration, and which promised to reimburse firms for the direct costs of registering. If the stylized de Soto/Doing Business view is true, and firms want to formalize but for the costs, then we should expect to see a large response from this intervention. Likewise, if firms really want to formalize but time-inconsistency means they have never gotten around to it, a limited time offer to reimburse registration costs and a nudge from an outsider might be expected to spur registration. In contrast, if firms have decided not to formalize because they don't think the benefits outweigh the costs, we would expect few firms to be at the margin where just the upfront registration cost alone was enough to change this calculus. Such firms would need additional incentive to register, and so we experiment by seeing how much we need to pay firms to get them to find it worthwhile to formalize.

We therefore designed the following four treatments:

Treatment 1: Information and Reimbursement. We designed an information brochure in consultation with the Chamber of Commerce and local Divisional Secretariat which clearly set out the advantages and disadvantages of registering with the DS and explained the steps required to register. This information brochure was given to firm owners; trained research assistants were available to answer any questions the firm owner had about how to register. Firm owners were also told that we would pay a reimbursement of 1000 LKR - slightly more than the average level of fees paid to register - if they registered within one 
month and mailed us a copy of their business registration certificate. This offer was presented in person and written on official university letterhead to increase credibility.

The information brochure was entitled "Could Business Registration Lead to the Success of Your Enterprise?". Issues covered included: what is meant by business registration, the reasons a business should be registered, the reasons some owners do not register, and myths about registration. The brochure also gave details of where to go to register, and the cost, time and documents required for registration.

Treatments 2, 3 and 4: Information and Payments. The other three treatment groups also received the information brochure, but instead of reimbursement owners were offered a larger monetary payment if they registered within one month of the offer. The amounts offered were 10,000, 20,000 and 40,000 LKR respectively (approximately US $\$ 88, \$ 175$ and $\$ 350$ at the time of treatment). This offer was delivered on a certificate which specified the name of the owner offered the treatment and the last date the registration could be submitted to us to qualify for payment. The certificate came with the signature of Dr. de Mel, and a project seal to increase credibility. We conducted an open house in both Colombo and Kandy where firm owners could come after receiving the offer to ask any questions. The open house also served to reassure the owners that the offer of payment was credible. To receive their payment firm owners had to return to the same location during a window of time and present their new business registration certificate along with their national identity card. To guard against false registrations we required the nature of the business and the address on the BRC to be the same as on the baseline survey. Where the two differed for a legitimate reason, the owner had to inform us in advance. In that case, they received payment only after we had verified the new address.

The payments offered are quite sizeable relative to the size of the firms and to the time required to complete the registration process. As noted above, the median profit for the firms in our sample was 25,000 LKR, so treatments 2, 3 and 4 were approximately half a month's, one month's, and two months' profits respectively. A firm earning 25,000 LKR per month faces no income tax, so the payments are also very large relative to the direct cost of formalizing (the roughly 1000 LKR fee) for these firms. The $90^{\text {th }}$ percentile of monthly profits in our data was 75,000 LKR, which would require an annual income tax of 33,000 LKR (3.7\% of income). So our larger treatment exceeds the annual income tax cost of formalizing if they were to report their entire income. ${ }^{7}$

\footnotetext{
${ }^{7}$ de Mel, McKenzie and Woodruff (2009) estimate that micro enterprise owners underestimate reported profits by as much as 30 percent. If firms in our sample are under-reporting profits by a similar amount, then the median firm would be liable for annual taxes of 3000 LKR, implying that our smallest payment would compensate for three years of tax payments. If firms under report profits in the survey, they might also do so in tax reports.
} 
One immediate question is then whether firms could easily register to take the payment offered, and then de-register the business to continue operating informally. If this were the case, our experiment would be less informative about the incentives needed to get firms to formalize. However, in practice this does not appear easy to do. Canceling of business registration can occur if the enterprise ceases to operate. The enterprise needs to notify the DS office within 3 months of closing the business, and provide certification from the local G.N. official to verify that the business is closed. Therefore for a firm to accept our payment and then revert back to unregistered status, they would have to actually close their business and have this verified, before re-opening it again.

Our sample size of 520 was randomly assigned by computer into these four treatment groups and a control group as follows. Firms were first stratified by province (Colombo or Kandy), Industry (retail, manufacturing, or services), whether or not they had more than 2 paid employees, and whether or not in the baseline survey they had said they would register if someone were to pay the costs, and had also said they perceived some benefit to registration. Then within each of these 24 strata we sorted firms according to their sales rank, and formed matched quintuplets. Where the number of firms in a strata was not perfectly divisible by 5 , the additional firms were randomly assigned within strata to one of the five treatment groups with equal probability. This method of randomization was chosen on the basis of the recommendations of Bruhn and McKenzie (2009) with the aim of increasing baseline balance and power, given that we only have 102-105 firms in each treatment group. The variables chosen for stratification were chosen on the basis that local regulations make the process of registration slightly different in Colombo and Kandy, while the incentives to register were a priori believed to possibly differ by industry, firm size, and self-professed desire to register.

The initial offers were given to treatment groups 1 and 2 in late February/early March 2009 (see timeline in Figure 2). Firms in these two treatment groups were given to the end of March/start of April to provide their business registration certificates and receive payment. Given budget constraints and the desire to map out as much of the demand curve for formality as possible, we waited to decide on the amount to offer treatment groups 3 and 4 until observing the take-up rates of these first groups. Treatment groups 3 and 4 were then given their offers in late April, with a deadline of late May to show their paperwork. However, on May 18 the Sri Lankan Government declared victory in the 25-year civil conflict, leading to a national holiday and making it difficult for paperwork to get processed toward the end of May. We therefore decided to give all four treatment groups an extra month to carry out their registration if they desired, with a new deadline of the end of July 2009. Any firm which had completed

its registration between the previous deadline and the new deadline was also eligible to receive the payment.

\subsection{Quasi-registration and actually receiving the treatment offer}


Owners of the firms assigned to treatment were asked to confirm their registration status on a follow-up visit in which we made the offer corresponding to their treatment group. We were surprised to learn that a non-trivial number of the firms were already registered with the DS. Recall that all of the firms stated they were not registered with the DS in the baseline survey. A handful of these firms had registered in the 3 to 4 months since the baseline survey (this was confirmed by examining the BRC, which shows the date of registration), but the majority of those registered had either misunderstood the question in the baseline survey or were what we term "quasi-registered". The latter refers to a number of cases where the business had been registered in some form, but the registration did not match the current circumstances of the business. For example, in some cases the business had been registered by another family member, who was no longer running it. In other cases the registration had been for another location. The firm thus had a BRC, but it didn't match the firm in all details. This BRC could still presumably be used to access government contracts or in dealing with a bank. We therefore chose not to offer the treatment to firms in this category. We subsequently also re-visited the control group firms to determine which of them also fell into this quasi-registered status.

In total, 152 out of the 415 firms which were assigned to one of the four treatment groups did not receive the registration offer. The majority of time (106 cases) this was because the firm was alreadyregistered or quasi-registered at the time of the baseline survey, as just described. In 14 cases, the business had closed since the baseline survey, in 18 cases, the owner could not be found in the follow-up, and in 14 cases the business had registered on its own between the baseline survey and the intervention. Five of the owners rejected the offer outright; we count these cases as having received the offer. Follow-up visits with the control group revealed 30 firms which were already registered, and a further 12 had closed or moved or couldn't be located.

Table 1 reports summary statistics for the full sample according to assignment to treatment, and also for the subsample which actually received the treatment offer (or was eligible to do so after rechecking in the control group). The randomization succeeded in achieving balance for both the variables explicitly stratified or matched on, and for other key variables. With the possible exception of treatment group 1 (the information and reimbursement only group), there is also balance in the share of the group already registered or quasi-registered. As a result, we cannot reject balance for any of the variables in the subsample for which the offers were actually made.

\section{The Demand for Formalization}

\subsection{Which Treatments Increased Formalization?}

We estimate both the intention-to-treat effect (effect of being randomized into one of the 4 different treatment groups), and treatment effect on the treated (effect of being randomized into one of the 
4 different treatment groups and actually being offered the treatment). The intention-to-treat effect is obtained by means of the following regression:

Registered During Intervention Window $w_{i}=\alpha+\beta$ 'TREATMENT ${ }_{\mathrm{i}}+\gamma^{\prime} \mathrm{STRATA}_{\mathrm{i}}+\varepsilon_{\mathrm{i}}$

Where TREATMENT $T_{i}$ is a vector of dummies for each of the four treatment groups, and STRATA $A_{i}$ is a vector consisting of dummies for each of the strata used in the randomization. To estimate the treatment effect on the treated we replace TREATMENT with dummies for actually being offered the treatments, and then instrument these with assignment to treatment.

Table 2 shows the results. Only 1 of the 104 firms in the information and reimbursement group registered during our intervention window, compared to 16 in the 10,000 LKR treatment group, 13 in the 20,000 LKR treatment group, and 30 in the 40,000 LKR treatment group. The large majority of firms registered during the initial month period given to them - only 8 registered when given the extra time and the new end of July deadline. During the intervention time window, 2 firms in the control group registered. Columns 1 and 2 show the treatment effects as proportions of those in each treatment group, while the TOT effects in Columns 3 and 4 are effectively these numbers as a proportion of those who were actually offered the treatment. Thus when only information and reimbursement of costs is offered, there is no significant effect, with fewer firms registering than the control group. The 10,000 LKR and 20,000 LKR offers have effects similar to one another (we can't reject equality), with 17 to 22 percent of firms registering in response to the offer. Meanwhile, 48 percent of those offered 40,000 LKR registered in response. The effect of the 40,000 LKR treatment is different from either the 10,000 or 20,000 LKR treatment at all standard significance levels. Controlling for the strata dummies increases slightly the precision of the estimates and the share of variation in registration explained by the regression, but does not change the magnitude of the coefficients - as one would expect given baseline balance.

In August 2009, we followed up with all of the 29 firms in the 40,000 LKR treatment group who were offered the payment but chose not to register We asked them why they had not done so. The firms can be divided into three groups. The largest number, 14, said they had started the process of registering, only to learn that, because they did not own the land they operated on, they would need to obtain the land owner's permission to register. In many of these cases, the land was owned by the government or a temple, and owners told us that registration was impossible. With this group we therefore made no further offers, concluding that land issues was the reason for lack of registering. Six of the firms told us they were willing to register at 40,000 LKR, but had either needed more time or had not understood the offer. We therefore gave them one more final month for the offer at 40,000, during which only one business registered. The final group of nine firms had not completed the registration process because they felt the benefits did not outweigh the costs even with the 40,000 LKR payment. We told these firms that we had some money left over from the project, and would increase the offer for a final offer of 80,000 LKR. Only 
two of the nine firms registered when given this higher offer. It therefore seems that these remaining informal firms are resolutely informal, with extra time or extra money not getting many more to register.

\subsection{Which owners formalized?}

Table 3 presents the results of probit estimation of the likelihood of registration for each of the three treatment groups given monetary incentives. This allows us to examine which characteristics of firms are correlated with greater demand for formalization. The base specification in column 1 contains dummies for the 20,000 LKR and 40,000 LKR treatment offers, controls for the variables we stratified on, and an indicator of whether the business operates on public land. We see the demand for formalization is higher in Colombo where the process is easier, although not significantly so at standard levels $(\mathrm{p}=0.108)$, and is 27 percentage points lower for businesses which operate on publicly owned land, an effect which is significant at the 1 percent level. There is no significant difference in demand to formalize by industry, pre-expressed willingness to register, or baseline size in terms of employment or sales.

The remaining columns examine alternative explanations that may enter into a firm owner's decision to formalize. Column 2 tests whether less knowledgeable and less informed owners are more likely to register, perhaps because the information is more useful to them. We see no statistically significant effects, and the point estimate suggests that, if anything, it may be more knowledgeable owners who register when given monetary treatments. Column 3 examines factors associated with the likely future costs of formalizing - these costs are expected to be higher for firms with higher profits (who would face more taxes) and who expect to have more workers (and thus face labor taxes). We see a negative and significant association with expecting to grow to 15 or more workers, where the costs of formalizing become greater due to labor regulations. Column 4 looks at the role of risk and time preference factors; we find no significant impact of being a hyperbolic discounter or of individuals saying they are risk seeking. ${ }^{8}$ The final column uses business assets at baseline as a proxy for wealth, as a test of liquidity constraints. The coefficient is positive and statistically insignificant, suggesting that it is not the case that poorer firms are more likely to respond to the incentives.

Overall we view the results as indicating that most of those becoming formal are informed owners who rationally weigh the costs and benefits of formalizing, or who face legal barriers because they operate on public property.

\section{What are the consequences of formalizing?}

\footnotetext{
${ }^{8}$ Risk preferences are measured on an 11-point scale taken from the German Socioeconomic Survey, which asks "are you generally a person who is fully prepared to take risks or do you try and avoid taking risks". Hyperbolic discounting is measured by asking firms hypothetical questions about how much they would be prepared to take today compared to 10,000 LKR in one month, and similarly for 5 months vs 6 months. 20 percent of the firms in our sample are classified as hyperbolic.
} 
We carried out three follow-up surveys to measure the impact of formalizing on firms (Figure 2). The first follow-up was in August 2010, corresponding to a period of between 12 and 18 months after firms were induced to register. We were able to re-interview 465 of the original 520 firms (89\%), with the most common reasons for attrition being not being able to find the owner ( 20 out of the 55 cases), the owner being abroad (9 out of 55 cases), and firm owners refusing to be re-interviewed ( 9 out of 55 cases). We cannot reject the null hypothesis that attrition is unrelated to treatment status at conventional significance levels ( $\mathrm{p}=0.17$ ). The second follow-up survey was conducted in March 2011, at period averaging 22 months after the start of the intervention We reached 445 firms in this round, with attrition again unrelated to treatment status ( $\mathrm{p}=0.35$ ). The final follow-up survey was conducted in December 2011, an average of 31 months after treatment. In this last survey 424 firms were interviewed with attrition again unrelated to treatment status $(\mathrm{p}=0.40)$. In addition, proxy reports were used to determine whether the business was still open for a further 59 firms. The remaining 37 firm owners were unable to be located, largely due to their having moved out of the study areas.

Table 4 examines whether any of the treatments is significantly associated with firm survival in the fourth round survey, or with reporting profits in any survey round. It does this by estimating equation (1) with survival or reporting profits as the dependent variable. In all cases, we find no significant relationship between treatment and the likelihood of survival or reporting profits in our follow-up surveys. Moreover, Appendix Table 2 shows that treatment does not appear to be associated with which firms survive. The Appendix reports the same characteristics as in Table 1, and shows balance on baseline characteristics for the firms surviving to the final survey. As a result we ignore attrition in what follows.

\subsection{What do firms say the consequences of formalizing are?}

The August 2010 survey asked the firms that formalized as a result of our intervention if they had benefited from being formal. The most common response, given by 36 percent of firms, was that they had yet to see any benefit from registering. The next most common response, coming from 20 percent of firms, was an answer related to improvements in the image of the business. This encompasses answers like "it is good publicity", "customers trust the business more", and "social validity". Other common responses refer to feeling more secure and protected (12 percent), and to fact that the business registration could be used in the future to help obtain business loans (10 percent). Very few firms claimed to have obtained a loan, or to have received a government contract as a result of formalizing.

\subsection{Econometric estimation of the consequences of formalizing}


We use the follow-up data to estimate the impact of formalizing on firm outcomes, intermediate channels, and attitudes of firm owners. For outcome $Y$ and firm $i$ in randomization strata $s$, we estimate:

$$
Y_{i, t}=\alpha_{i, s}+\beta \text { Formal }_{i}+\gamma Y_{i, 0}+\sum \delta_{t}+\varepsilon_{i, t}
$$

Where $\alpha_{i, s}$ are randomization strata fixed effects, $Y_{i, 0}$ is the baseline value of the dependent variable, $\delta_{t}$ are survey wave effects. Our main object of interest is in estimating $\beta$, the causal impact of becoming formal (defined in terms of being registered with the DS) on the outcome of interest. The inclusion of the lagged dependent variable increases power, and helps control for any selective attrition based on the outcome of interest. ${ }^{9}$ We pool together all rounds of follow-up data to increase power (McKenzie, 2011); Appendix Table 3 shows we cannot reject equality of impacts on profits across our three follow-up rounds ( $>$ >0.90). In addition, for the key outcomes of firm profits and firm sales, the March and December 2011 survey asked for each of the past 3 month's data, enabling us to run the specification in (2) with 7 months of observations per firm for these outcomes. Standard errors are clustered at the firm level. We instrument for formalization with three variables indicating assignment to the 10,000 LKR, 20,000 LKR, and 40,000 LKR treatments respectively. Since the information and reimbursement only treatment did not lead to any change in registration, it does not serve as an instrument and we drop this treatment group from this part of the analysis.

The treatments are valid instruments for being formal under the assumption that they affect the outcomes of interest only through changing registration status, and not through any other channel. An obvious concern with this assumption is that the grants given to the firm owner may have had independent impacts on the business, through alleviating credit constraints. If such impacts are positive, using the treatment assignment as an instrument will overstate the gains to formalizing, providing us with an upper bound of the consequences of formalizing.

An alternative approach is to control for capital stock in regression (2), and thereby attempt to identify the impact of formalizing through channels other than changing capital stock. We use log capital stock as the control, given the skewness of this variable. This will net out any impact of the grants on capital stock. But the inclusion of capital stock as a control also removes the effect of changes in capital stock that come from formalizing. This might arise, for example, if formalizing increases access to credit, enabling firms to invest more. This specification should therefore serve as a lower bound for the impact of formalizing. In order for this approach to be valid, we have to make what Imai et al. (2011) refer to as a sequential ignorability assumption. In our context, this amounts to assuming that, conditional on treatment assignment, the lagged dependent variable, and the strata randomization controls, capital stock is independent of the outcome of interest. Given the rich set of controls used here, this may be reasonable.

\footnotetext{
${ }^{9}$ Recall that we can not reject that attrition is unrelated to treatment status.
} 


\subsection{Impact on major firm outcomes}

Table 5a presents the results of estimating equation (2) for the key outcomes of firm profits, sales, employment, and capital stock. Consider first the impact on firm profits. Column 1 shows an upper bound estimate of 13,706 LKR increase in monthly profits from formalizing, which is large relative to the mean profits in the control group of 30,537 LKR and significant at the 10 percent level. The lower bound estimate obtained when we control for capital stock is one-third smaller $(8,996)$, and not significant at standard levels $(\mathrm{p}=0.265)$. These point estimates are sizeable relative to both the upfront costs of registering (1000 LKR), and the annual income taxes for a typical firm of this level (3000 LKR). They are also sizable relative to the incentives provided to register. Columns 2 and 3 show the results of truncating profits at the $99^{\text {th }}$ and $95^{\text {th }}$ percentiles respectively. The latter more than halves the point estimate of the impact on profits. In contrast, log profits are also significant (column 4). Columns 5-7 show large positive coefficients for sales, which are not statistically significant in levels, and which halve when we control for capital stock. The remaining columns show positive, but insignificant, impacts on employment and capital stock.

To see where this statistically significant increase in profits is coming from, Figure 3 plots the cumulative distribution function of profits in our final round survey for the combined monetary treatment groups and for the control group. We see that the distributions are extremely similar to one another right up until the very top tail, where they diverge. The significant mean effect is thus being driven by this handful of firms which formalized and experienced large increases in profits, whereas for most of the distribution the treatment does not influence profits.

An obvious question is then whether these large profits in the upper tail represent genuine changes or whether they represent measurement error and/or idiosyncratic shocks for a few firms. To address this issue, in June 2011 we conducted open-ended discussions with a set of firms experiencing large increases in profits after registering. We wanted to see whether they had taken specific actions following registration and whether they appeared to benefit from doing so. Although small in number, these more detailed case studies provide support for the idea that a few firms had benefited substantially from formalizing. For example, two of the firms were in the vehicle repair business - one automobiles and one autorickshaws. Both said that an important consequence of registration was the ability to become an official parts distributors for an auto parts manufacturer. Previously, they had purchased parts from another dealer, i.e., at higher than the wholesale price. Both had also undertaken expansions of the physical facilities, with one adding an auto lift and a customer waiting room, while increasing employment from 2 to 8 workers. A saw mill which registered said the key was to be able to put the forest service stamp on the receipts which he issued. The stamp allows customers to transport the wood across 
municipal boundaries without obtaining further permissions. His estimate was that he had previously lost 25 percent of sales to other mills which could provide this stamp. Finally, a grocery store and tea (snack) shop had used the license to obtain a loan to purchase a delivery truck. The truck was used in the business, but also leased out. On his own, he had gone to the health department to request a health inspection for his tea shop. He was intent on improving his score so that he would obtain a health sticker he could display, and so that he could open a bakery and wholesale bread. A final case was of a fish market vendor, who had used the 40,000 LKR grant to buy a freezer which he could then use to increase and maintain his stock, and then increased advertising and used his registration to print a receipt book he could use to give receipts to restaurants who wanted fish. In all these cases, there were clear changes in the business operation, and in the attitude and vision of the owners. Hence, we believe this growth at the top tail of the distribution is genuine. But such firms were rare. Most firms that had formalized had not seen such improvements.

\subsection{Impact on Mediating Channels}

The above analysis suggests that formalization has not had significant impacts on key outcomes for most firms that formalized, but that it has helped a handful of firms which grew substantially. Our followup surveys span a period of 15 to 31 months after treatment. This should be a sufficient period to detect effects for most firms. Nevertheless, one concern is that the standard errors in Table 5a are relatively large, reflecting relatively low power to detect effects. The CDF in Figure 3 is comforting in this regard, as it shows strikingly similar distributions of profits for treatment and control for most of the distribution. However, a further approach to determining whether formalization seems to be benefitting firms is to look for evidence on the mediating channels through which advocates claim formalization should benefit firms. Impacts through these intermediate channels may be quicker to materialize. The intermediate channels may also suffer from less variation, enabling more precision.

Table $5 \mathrm{~b}$ presents the impact of formalizing on channels through which formalization might be expected to influence firm outcomes. The assumption that the grants are not independently affecting these channels is more plausible here than for profits or capital stock, and consistent with this, we find that the upper and lower bounds are quite close to one another. We therefore just present the upper bound estimates, which do not control for capital stock.

The results show little evidence that formalizing has impacted firms through most of the main channels through which formalization is often hypothesized to have benefits. We find no significant effect on relationships with the financial sector - applying for business or personal loans or having a business bank account - on relationships with the government - having an electricity connection in the business

name, applying for a government contract, making sales to the government, or participating in any government SME program. Moreover, the point estimates on most of these variables are close to zero, 
with relatively small confidence intervals in most cases. The point estimates also suggest businesses are not any more likely to pay taxes, and the point estimate is actually negative on the amount of taxes paid. We do not find any evidence that businesses are changing location after formalizing.

The only intermediate channels which show significant impacts are the use of receipt books $(\mathrm{p}=0.007)$, and an increase in advertising $(\mathrm{p}=0.003)$. Both outcomes are still statistically significant at standard levels even if we conservatively control for multiple hypothesis testing of 14 intermediate channels by multiplying each by 14 to obtain Bonferroni p-values. This is consistent with the nonexperimental evidence in McKenzie and Sakho (2010) who suggest the main effect of formalizing in Bolivia is to expand sales through increasing the use of receipts. However, to date the evidence from Figure 3 and Table 5a suggests that for most firms this channel has not yet resulted in significantly higher profitability.

\subsection{Impacts on attitudes}

The tea shop owner who contacted the health department about an inspection raises the question of whether formalization may have changed attitudes about the government and market regulations more generally. Di Tella et al. (2007) study formalization in a different domain - formal titles among land squatters - and find very large effects of obtaining formal property title on beliefs that favor the workings of the market. Motivated partly by this, in the first follow-up survey we asked a number of questions on trust and attitudes which enable us to examine the impact of formalizing on the attitudes that firm owners have towards government, the courts and police, and taxation.

Table 5c shows the results. We find very strong positive effects of formalizing on trust in the provincial government and trust in the municipal government, the two levels of government that business owners interact with during the registration process. The p-value on trust in the provincial government is 0.007 , so remains significant even after controlling for multiple hypothesis testing over the 9 outcomes in the table. In contrast, we find no significant impact on trust in the national government, trust in the courts, or trust in the police, and formalizing does not make firms any more likely to be confident in the police and courts to resolve business disputes.

One interpretation of this increase in trust is that those firms that formalized had to deal with the DS and municipal governments in the registration process, and may have been surprised to find the process less burdensome and less subject to bribes than they had imagined. That is, the process of formalizing might be the lever for attitude change, by demonstrating that these levels of government can be trusted. An alternative potential explanation is that the change in attitudes is a consequence of being formalized. That is, if firm owners no longer worry about the provincial and municipal governments shutting them down for lack of compliance, they may be more trusting of these levels of government. 
We also see formalizing leads to changes in attitudes towards taxes. Firms that formalize are much more likely to agree that part of being a good citizen means paying taxes. However, they are no more likely to think the government spends its revenue on items important to these firm owners, and also significantly more likely to agree that the government charges businesses too much in terms of taxes. Recall that actual taxes are quite low for most businesses in this sample, so this perception contrasts with the reality facing most firms.

\section{Discussion and External Validity}

Our baseline sample was a random sample of informal firms in the two largest cities in Sri Lanka. As with all microeconomic studies, there is a question of external validity. We present evidence here to suggest that our results from Sri Lanka are likely to be informative of constraints to formalizing firms in other countries.

First, we note that the pattern of informality with regard to firm size, and what firms say are the potential advantages and disadvantages of formalizing are similar to those we see in other countries for which data exists. Appendix Figure 1 compares municipal government and tax authority registration rates by firm size in Sri Lanka, Bangladesh and Mexico. In all three countries, the data are representative of firms in the largest urban areas. ${ }^{10}$ Sri Lanka has tax registration rates which lie between those in Mexico and Bangladesh. The figure shows that in these other countries, registration also typically occurs over the size range considered in our study - not with the smallest microenterprises.

The Bangladesh survey asked firm owners what they saw as the main advantages of being formal. Owners give responses which are similar to those in the Sri Lanka survey: links to bank financing, better reputation for the business, a lower chance of being fined, and the ability to operate visibly at a large scale without fear of being caught. Smaller and more informal firms in Bangladesh are more likely to say they see no potential benefits and all firms say the main disadvantages were paying taxes and having to deal with the cost and process of registering (McKenzie, 2010). These same channels also appear in discussions of the costs and benefits of formalizing in different Latin American countries (Perry et al, 2007; World Bank, 2009).

As a result, it seems reasonable to believe that our results are informative outside Sri Lanka about the number of firms at the margin who will be induced to formalize by relatively small changes in the costs and benefits, and also about the characteristics of those firms. Our results suggest that taking the costs of

\footnotetext{
${ }^{10}$ The Sri Lankan data come from the Sri Lankan Longitudinal Survey of Entrepreneurs, which draws a random sample of 2255 firms from household listings in 31 cities outside the northern province. In Mexico, the data are from the 2002 version of the National Microenterprise survey, conducted in urban areas with a sample drawn from a household-based nationally representative labor survey. The Bangladesh survey data come from a census of 55,817 firms in randomly selected sampling areas from 19 districts conducted by the World Bank in 2009-2010.
} 
registering from the levels in Sri Lanka to zero induces few firms to formalize. However increasing the benefits further (in our case by paying firms) induces more firms to formalize. This is consistent with recent cross-country panel data, in which Klapper and Love (2010) find that only changes in business environment reforms which involve more than a 40 percent reduction in costs are associated with changes in firm entry. ${ }^{11}$

\section{Conclusions}

Prior to the intervention, owners of unregistered firms were either ignorant of, or vastly overestimated the costs of registration. We might therefore have expected that simply informing firms about the costs of registration would be sufficient to induce registration. But we find that information and reimbursement for the modest direct costs do not result in any increase in registration. Instead, registration is spurred only when the information is combined with incentive payments.

The incentive required to induce registration is modest compared to reported profits levels of the sample enterprises. A payment of two month's profit is sufficient to induce half of the firms to register. Among those not registering after receiving an offer of this magnitude, more than half took some steps toward registering. They stopped only when learning that issues of land ownership would prevent them from registering without paying significant fees to landlords, temples, or the government. Thus, in the absence of land issues, the net costs of formality appear to be modest for almost all of the informal firms represented by our sample. However, the net benefit also appears modest for most firms. While we do find an increase in profits after formalization, this mean treatment effect seems to be driven by a successful upper tail. Firms that formalize do more advertising and are more likely to use receipt books, but don't appear to get the more touted benefits of formalizing such as increased access to credit, obtaining government contracts, or participating in government programs. Most firms seem therefore to be rationally refraining from formalizing, while a few seem to be suboptimally informal.

This finding is important for two reasons. First, while governments clearly should not mimic our experiment with a policy of direct payments, the results do suggest that modest increases in the perceived benefits of being formal could be expected to dramatically increase the demand to formalize among firms

\footnotetext{
${ }^{11}$ Our results are also consistent with evidence from an unpublished parallel experiment in Lima, Peru which randomly encouraged firms to obtain a municipal license (Jaramillo, 2009; Alcázar et al, 2010). About one-quarter of firms offered information and reimbursement of direct costs obtained the municipal license. One-third of those who didn't register reported problems with other regulations such as zoning, consistent with our finding that land issues prevent many firms from registering. A follow-up survey 18 months after baseline failed to find any significant impact of registration obtaining the municipal license on firm size, access to credit, or profitability, but their power to detect an effect is low. Moreover, since banks and the government typically require a tax license rather than municipal license as proof of formality in many countries, there may be less ex ante reason to expect a positive impact on firms of municipal registration.
} 
currently operating informally. Second, despite the pervasive interest of governments around the world in trying to increase the size of their formal sector, our results overall suggest little in the way of pent-up demand to become formal among existing firms. Nevertheless, our results do show an increase in trust in the government as a result of formalizing. It is possible that formalizing a large number of firms would offer broader benefits to society in terms of trust.

Finally, it should be noted that our study measures the benefits of formalizing for firms which are already in business. There may well be benefits from the simplification of registration at the extensive margin, if high-ability entrepreneurs not currently operating a business are induced to enter. Measuring such impact remains a key area for future research.

\section{References}

Alcázar, Lorena, Raúl Andrade, and Miguel Jaramillo, 2010. "Panel/tracer study on the impact of business facilitation processes on enterprises and identification of priorities for future business enabling environment projects in Lima, Peru - Report 5: impact evaluation after the third round", Report to the International Finance Corporation, Mimeo.

Bertrand, Marianne and Francis Kramarz, 2002, "Does Entry Regulation Hinder Job Creation? Evidence From The French Retail Industry," The Quarterly Journal of Economics, vol. 117(4), pp. 1369-1413.

Bruhn, Miriam. 2011. "License to sell: the effect of business registration reform on entrepreneurial activity in Mexico." Review of Economics and Statistics, 93(1): 382-86.

Bruhn, Miriam and David McKenzie, 2009, "In Pursuit of balance: Randomization in Practice in Development Field Experiments," American Economic Journal: Applied Economics 1(4): 200-232.

de Mel, Suresh, David McKenzie and Christopher Woodruff. 2009, "Measuring Microenterprise Profits: Must we ask how the sausage is made?," Journal of Development Economics, 88(1): 19-31.

de Mel, Suresh, David McKenzie and Christopher Woodruff. 2008. "Returns to Capital in Microenterprises: Evidence from a Field Experiment", Quarterly Journal of Economics 123(4): 1329-72.

De Soto, Hernando. 1989. The Other Path, New York: Harper and Row Publishers.

Di Tella, Rafael, Sebastian Galiani and Ernesto Schargrodsky, 2007. "The formation of beliefs: Evidence from the allocation of land titles to squatters", Quarterly Journal of Economics 122(1): 209-241.

Djankov, Simeon, Rafael La Porta, Florencio Lopez-de-Silanes and Andrei Schleifer 2002. "The Regulation of Entry," Quarterly Journal of Economics, 117(1), pp. 1-37.

Hsieh, Chang-tai and Peter J. Klenow, 2009, "Misallocation and Manufacturing TFP in China and India," Quarterly Journal of Economics, 124(4): 1403-48.

Fajnzylber, Pablo, William Maloney and Gabriel Montes-Rojas 2011. "Does formality improve microfirm performance? Evidence from the Brazilian SIMPLES program", Journal of Development Economics 94: 262-76.

Imai, Kosuke, Luke Keele, Dustin Tingley and Teppei Yamamoto, 2011. "Unpacking the black box: Learning about causal mechanisms from experimental and observational studies", Mimeo. Princeton University.

International Finance Corporation (IFC) 2009. Doing Business 2010: Reforming through difficult times. IFC: Washington, D.C.

Jaramillo, Miguel, 2009. "Is there demand for formality among informal firms? Evidence from microfirms in downtown Lima”, German Development Institute Discussion Paper 12/2009. 
Kaplan, David, Eduardo Piedra, and Enrique Seira. 2011. "Entry regulation and business start-ups: Evidence from Mexico" Journal of Public Economics 95(11-12): 1501-15.

Klapper, Leora, Luc Laeven and Raghuram Rajan. 2006. "Entry regulation as a barrier to entrepreneurship", Journal of Financial Economics 82(3): 591-629

Klapper, Leora and Inessa Love. 2010. "The impact of business environment reforms on new firm registration", World Bank Policy Research Working Paper no. 5493.

La Porta, Rafael and Andrei Shleifer. 2008. "The Unofficial economy and economic development", Brookings Papers on Economic Activity 2: 275-363.

Levy, Santiago, 2008, Good Intentions, Bad Outcomes: Social Policy, Informality and Economic Growth in Mexico, Washington: Brookings Institution Press

Maloney, William. 2004. "Informality Revisited", World Development 32(7): 1159-78.

McKenzie, David. 2010. "Dimensions of informality in Bangladesh", Mimeo. World Bank.

McKenzie, David. 2011. "Beyond baseline and follow-up: The case for more $\mathrm{T}$ in experiments", Journal of Development Economics, forthcoming.

McKenzie, David and Yaye Seynabou Sakho. 2010. "Does it pay firms to register for taxes? The impact of formality on firm profitability", Journal of Development Economics 91(1): 15-24.

Monteiro, Joana and Juliano Assunção (2011) "Coming out of the shadows? Examining the impact of bureaucracy simplification and tax cut on formality in Brazilian microenterprises", Journal of Development Economics, forthcoming.

Mullainathan, Sendhil. 2008. "Development Economics Through the Lens of Psychology", Mimeo. Harvard University.

Perry, Guillermo, William Maloney, Omar Arias, Pablo Fajnzylber, Andrew Mason and Jaime Saavedra. 2007. Informality: Exit and Exclusion. World Bank Latin America and Caribbean Studies: World Bank, Washington D.C.

World Bank. 2009. Increasing Formality and Productivity of Bolivian Firms. World Bank, Washington D.C. 


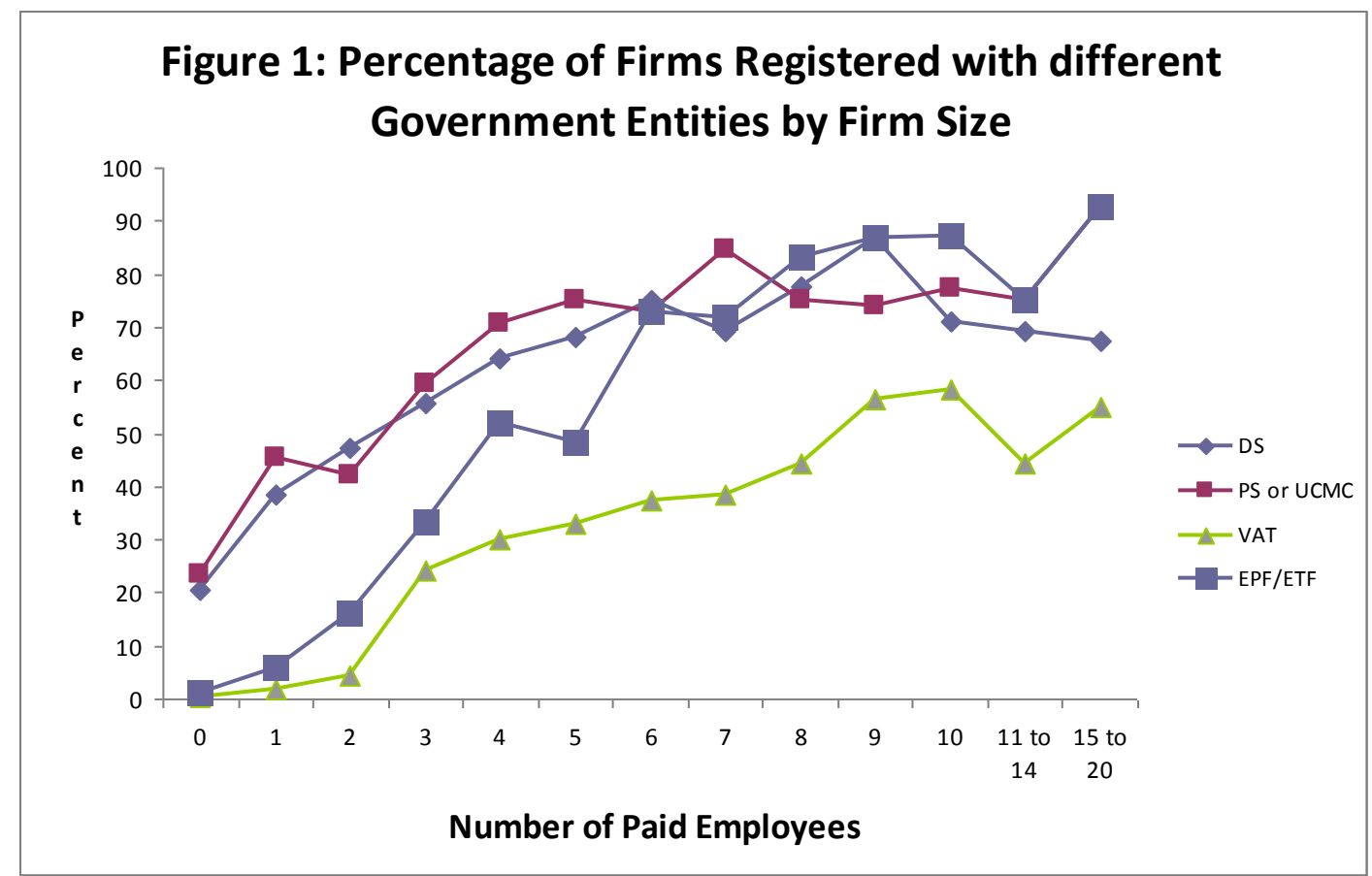

Figure 2: Timeline

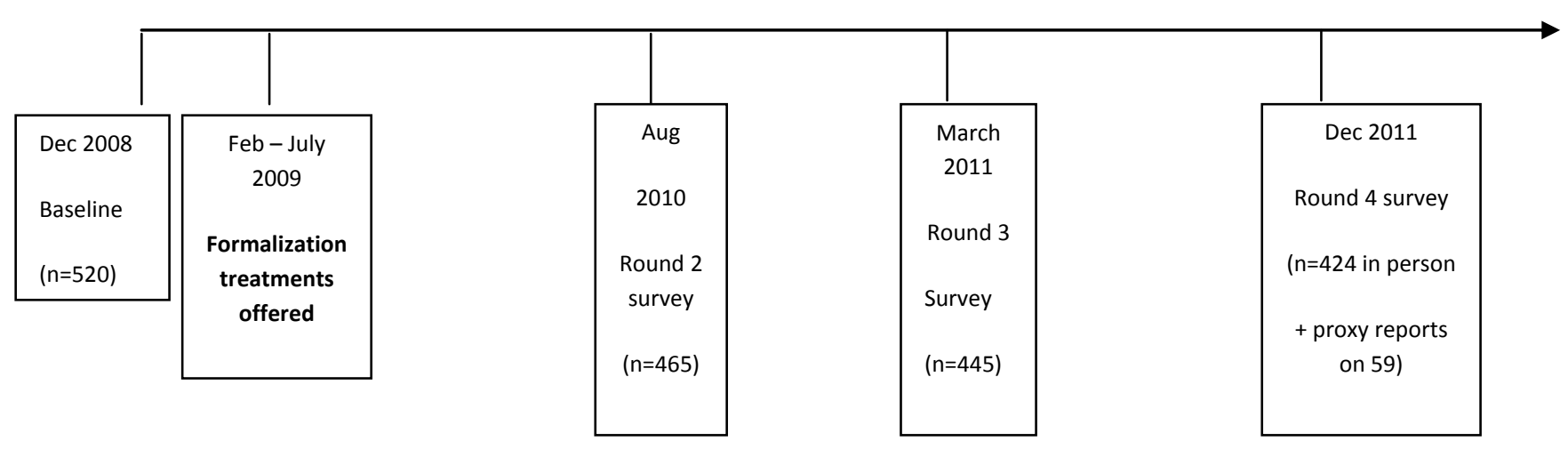


Figure 3: Distribution of Final Round Real Profits by Treatment Status

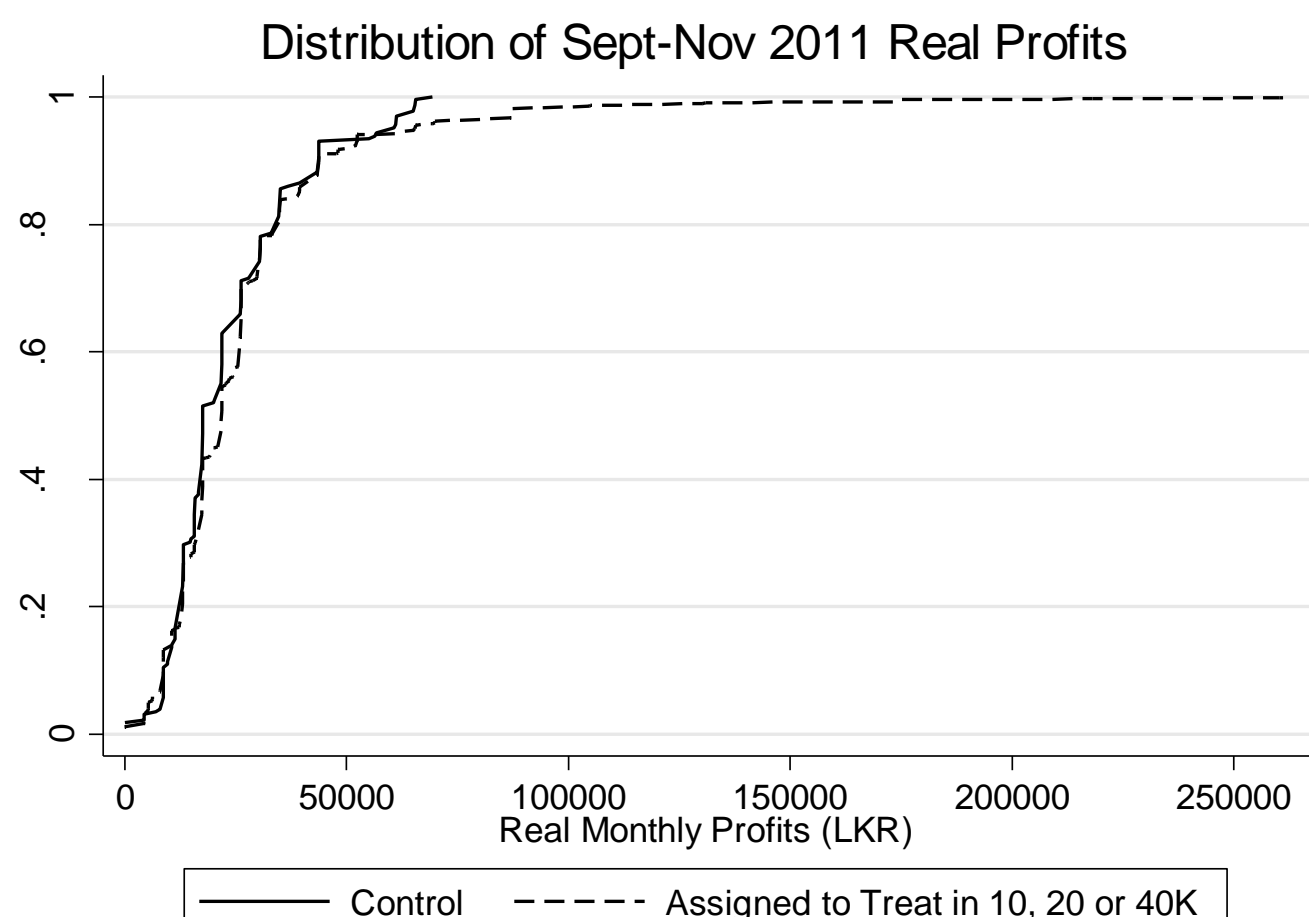


Table 1: Summary Statistics by Treatment Group

Panel A: Assignment to Treatment

\begin{tabular}{|c|c|c|c|c|c|c|}
\hline & $\begin{array}{c}\text { Treatment } \\
\text { Group } 1\end{array}$ & $\begin{array}{c}\text { Treatment } \\
\text { Group } 2\end{array}$ & $\begin{array}{c}\text { Treatment } \\
\text { Group } 3\end{array}$ & $\begin{array}{c}\text { Treatment } \\
\text { Group } 4\end{array}$ & Control & $\begin{array}{c}\text { F-test of equality } \\
\text { p-value }\end{array}$ \\
\hline \multicolumn{7}{|l|}{ Variables stratified or matched on } \\
\hline Retail & 0.23 & 0.22 & 0.24 & 0.23 & 0.24 & 0.998 \\
\hline Manufacturing & 0.34 & 0.34 & 0.32 & 0.31 & 0.31 & 0.993 \\
\hline Services & 0.43 & 0.44 & 0.44 & 0.46 & 0.45 & 0.996 \\
\hline Colombo & 0.50 & 0.50 & 0.50 & 0.52 & 0.49 & 0.993 \\
\hline More than 2 paid workers & 0.58 & 0.58 & 0.60 & 0.56 & 0.60 & 0.971 \\
\hline Says would register and sees benefit to doing so & 0.49 & 0.48 & 0.48 & 0.49 & 0.48 & 0.999 \\
\hline Sales in last month & 218570 & 153184 & 180691 & 160159 & 213310 & 0.497 \\
\hline Median of sales last month & 90000 & 92500 & 100000 & 100000 & 90000 & \\
\hline \multicolumn{7}{|l|}{ Variables not stratified or matched on } \\
\hline Doesn't keep records & 0.49 & 0.54 & 0.55 & 0.55 & 0.47 & 0.649 \\
\hline Years of Education of Owner & 11.07 & 10.68 & 10.89 & 11.43 & 10.54 & 0.082 \\
\hline Number of Paid employees & 2.93 & 3.13 & 3.10 & 3.00 & 3.15 & 0.905 \\
\hline Registered at the Pradeshiya Saba & 0.71 & 0.66 & 0.71 & 0.67 & 0.62 & 0.572 \\
\hline Profits in last month & 29679 & 32822 & 32634 & 36705 & 37585 & 0.662 \\
\hline Given Treatment Offer (or eligible for it if control) & 0.75 & 0.63 & 0.63 & 0.58 & 0.61 & 0.070 \\
\hline Sample Size & 104 & 104 & 105 & 102 & 105 & \\
\hline \multicolumn{7}{|c|}{ Panel B: Given Treatment Offer (or Eligible for it if Control) } \\
\hline & Treatment & Treatment & Treatment & Treatment & & F-test of equality \\
\hline & Group 1 & Group 2 & Group 3 & Group 4 & Control & p-value \\
\hline Retail & 0.19 & 0.23 & 0.20 & 0.19 & 0.23 & 0.941 \\
\hline Manufacturing & 0.38 & 0.37 & 0.38 & 0.39 & 0.36 & 0.997 \\
\hline Services & 0.42 & 0.40 & 0.42 & 0.42 & 0.41 & 0.998 \\
\hline Colombo & 0.42 & 0.43 & 0.33 & 0.39 & 0.39 & 0.790 \\
\hline More than 2 paid workers & 0.50 & 0.48 & 0.50 & 0.41 & 0.53 & 0.707 \\
\hline Says would register and sees benefit to doing so & 0.56 & 0.45 & 0.61 & 0.54 & 0.59 & 0.379 \\
\hline Sales in last month & 138985 & 136883 & 146917 & 150559 & 196391 & 0.780 \\
\hline Doesn't keep records & 0.54 & 0.60 & 0.56 & 0.64 & 0.52 & 0.609 \\
\hline Years of Education of Owner & 10.81 & 10.38 & 10.65 & 11.19 & 10.19 & 0.241 \\
\hline Number of Paid employees & 2.64 & 2.98 & 3.05 & 2.61 & 2.77 & 0.695 \\
\hline Registered at the Pradeshiya Saba & 0.64 & 0.60 & 0.62 & 0.54 & 0.59 & 0.834 \\
\hline Profits in last month & 26449 & 31270 & 30945 & 30759 & 33754 & 0.800 \\
\hline Sample Size & 78 & 65 & 66 & 59 & 64 & \\
\hline
\end{tabular}


Table 2: Treatment Effects

Dependent Variable: Registered During Intervention Window

\begin{tabular}{|c|c|c|c|c|}
\hline & \multicolumn{2}{|c|}{ Intention-to-treat } & \multicolumn{2}{|c|}{ Treatment on the Treatec } \\
\hline & OLS & OLS & IV & IV \\
\hline & (1) & (2) & (3) & (4) \\
\hline \multirow[t]{2}{*}{ Information and Reimbursement Treatment } & -0.00943 & -0.0101 & -0.0126 & -0.0138 \\
\hline & $(0.0165)$ & $(0.0254)$ & $(0.0219)$ & $(0.0286)$ \\
\hline \multirow[t]{2}{*}{ 10,000 Rs Treatment } & $0.135^{* * *}$ & $0.134 * * *$ & $0.216 * * *$ & $0.214^{* * *}$ \\
\hline & $(0.0380)$ & $(0.0380)$ & $(0.0576)$ & $(0.0515)$ \\
\hline \multirow[t]{2}{*}{ 20,000 Rs Treatment } & $0.105^{* * *}$ & $0.105^{* * *}$ & $0.167^{* * *}$ & $0.167^{* * *}$ \\
\hline & $(0.0350)$ & $(0.0387)$ & $(0.0534)$ & $(0.0508)$ \\
\hline \multirow[t]{2}{*}{ 40,000 Rs Treatment } & $0.275^{* * *}$ & $0.273 * * *$ & $0.476 * * *$ & $0.471 * * *$ \\
\hline & $(0.0473)$ & $(0.0453)$ & $(0.0691)$ & $(0.0598)$ \\
\hline Strata/Quintuplet dummies & No & Yes & No & Yes \\
\hline Observations & 520 & 520 & 520 & 520 \\
\hline R-squared & 0.102 & 0.284 & & \\
\hline \multicolumn{5}{|l|}{ P-values for testing: } \\
\hline 10,000 Rs Treatment $=20,000$ Treatment & 0.5320 & 0.5264 & 0.4993 & 0.4470 \\
\hline 10,000 Rs Treatment $=40,000$ Treatment & 0.0152 & 0.0086 & 0.0021 & 0.0002 \\
\hline \multicolumn{5}{|c|}{ Note: } \\
\hline \multicolumn{5}{|c|}{ Robust standard errors in parentheses, ${ }^{* * *} p<0.01,{ }^{* *} p<0.05, * p<0.1$} \\
\hline \multicolumn{5}{|c|}{$\begin{array}{l}\text { Treatment on the treated instruments whether people actually received the offer of this } \\
\text { treatment with whether they were assigned to receive this offer. }\end{array}$} \\
\hline
\end{tabular}


Table 3: Among Firms Offered Money, Which Ones Formalized?

Marginal effects from probit estimation of Registration among sample offered 10,000, 20,000 or 40,000 treatments

\begin{tabular}{|c|c|c|c|c|c|}
\hline & (1) & (2) & (3) & (4) & (5) \\
\hline \multirow[t]{2}{*}{ 20,000 Rs Treatment } & -0.0216 & -0.0240 & -0.00650 & -0.0169 & -0.0490 \\
\hline & (0.0886) & (0.0892) & (0.0877) & (0.0886) & $(0.0937)$ \\
\hline \multirow[t]{2}{*}{ 40,000 Rs Treatment } & $0.307 * * *$ & $0.311 * * *$ & $0.302 * * *$ & $0.311^{* * *}$ & $0.312 * * *$ \\
\hline & (0.0901) & (0.0908) & (0.0917) & (0.0903) & (0.0924) \\
\hline \multirow[t]{2}{*}{ Colombo } & 0.132 & 0.0859 & $0.143^{*}$ & 0.127 & $0.162^{*}$ \\
\hline & (0.0831) & $(0.0859)$ & (0.0833) & (0.0844) & (0.0914) \\
\hline \multirow[t]{2}{*}{ Retail } & 0.00266 & 0.0370 & -0.0204 & 0.00226 & -0.0403 \\
\hline & $(0.102)$ & $(0.105)$ & $(0.101)$ & $(0.100)$ & $(0.100)$ \\
\hline \multirow[t]{2}{*}{ Manufacturing } & -0.0361 & -0.0241 & -0.0296 & -0.0294 & -0.105 \\
\hline & $(0.0813)$ & $(0.0822)$ & $(0.0816)$ & $(0.0819)$ & $(0.0844)$ \\
\hline \multirow[t]{2}{*}{ More than 2 paid workers } & 0.0515 & 0.0867 & 0.0744 & 0.0694 & 0.0112 \\
\hline & (0.0795) & (0.0804) & (0.0805) & (0.0808) & (0.0859) \\
\hline \multirow[t]{2}{*}{ Says would register and sees benefit to doing so } & 0.0377 & 0.0609 & 0.0444 & 0.0450 & 0.0434 \\
\hline & (0.0769) & (0.0779) & $(0.0775)$ & $(0.0766)$ & (0.0794) \\
\hline \multirow[t]{2}{*}{ log monthly sales in December 2008} & -0.0259 & -0.0255 & 0.00358 & -0.0288 & -0.0377 \\
\hline & $(0.0421)$ & $(0.0417)$ & (0.0531) & $(0.0415)$ & $(0.0462)$ \\
\hline \multirow[t]{2}{*}{ Operate on publicly owned premises } & $-0.269 * * *$ & $-0.278 * * *$ & $-0.265 * * *$ & $-0.270 * * *$ & $-0.234 * * *$ \\
\hline & $(0.0744)$ & $(0.0716)$ & $(0.0754)$ & $(0.0737)$ & $(0.0849)$ \\
\hline \multirow[t]{2}{*}{ Education of Owner (years) } & & -0.0126 & & & \\
\hline & & (0.0132) & & & \\
\hline \multirow[t]{2}{*}{ Digitspan recall of owner } & & 0.0388 & & & \\
\hline & & $(0.0303)$ & & & \\
\hline \multirow[t]{2}{*}{ Owner knows cost of registering } & & 0.118 & & & \\
\hline & & (0.0792) & & & \\
\hline \multirow[t]{2}{*}{ Expects to have 15 or more employees in 5 years } & & & $-0.156^{* *}$ & & \\
\hline & & & (0.0748) & & \\
\hline \multirow[t]{2}{*}{ Profits in December 2008 exceed income tax threshold } & & & -0.0805 & & \\
\hline & & & (0.0993) & & \\
\hline \multirow[t]{2}{*}{ Hyperbolic discounter } & & & & -0.0422 & \\
\hline & & & & (0.0952) & \\
\hline \multirow[t]{2}{*}{ Risk seeker } & & & & 0.0284 & \\
\hline & & & & (0.0185) & \\
\hline \multirow[t]{2}{*}{ Log Business Assets in December 2008} & & & & & 0.0499 \\
\hline & & & & & $(0.0305)$ \\
\hline Observations & 181 & 181 & 181 & 181 & 163 \\
\hline
\end{tabular}

Note:

Robust standard errors in parentheses, ${ }^{* * *} p<0.01,{ }^{* *} p<0.05, * p<0.1$ 
Table 4: Does treatment status predict survival or reporting profits in survey

\begin{tabular}{lcccc}
\hline & $(1)$ & \multicolumn{2}{c}{$(2)$} & \multicolumn{2}{c}{$(3)$} & $(4)$ \\
& $\begin{array}{c}\text { In business } \\
\text { at R4 }\end{array}$ & $\begin{array}{c}\text { Report profits } \\
\text { in R2 }\end{array}$ & $\begin{array}{c}\text { Report profit } \\
\text { in R3 }\end{array}$ & $\begin{array}{c}\text { Report profits } \\
\text { in R4 }\end{array}$ \\
\hline Information and Reimbursement Treatment & 0.000653 & 0.0556 & 0.0266 & 0.0531 \\
& $(0.0408)$ & $(0.0569)$ & $(0.0543)$ & $(0.0618)$ \\
10,000 Rs Treatment & 0.00231 & 0.00747 & -0.0600 & -0.0719 \\
& $(0.0428)$ & $(0.0567)$ & $(0.0592)$ & $(0.0682)$ \\
20,000 Rs Treatment & 0.0203 & 0.0190 & 0.0667 & 0.0571 \\
& $(0.0399)$ & $(0.0559)$ & $(0.0517)$ & $(0.0632)$ \\
40,000 Rs Treatment & 0.00114 & 0.0425 & -0.0462 & -0.0140 \\
& $(0.0428)$ & $(0.0572)$ & $(0.0591)$ & $(0.0649)$ \\
Observations & & & & \\
F-test p-value that jointly zero & 483 & 520 & 520 & 520 \\
\hline All regres & 0.9849 & 0.8262 & 0.1049 & 0.2751 \\
\hline
\end{tabular}

All regressions include controls for randomization strata.

Robust standard errors in parentheses.

$*, * *$, and ${ }^{* * *}$ indicate significance at the 10,5 and 1 percent significance levels respectively. 
Table 5a: Effect of formalizing on firm outcomes

\begin{tabular}{|c|c|c|c|c|c|c|c|c|c|c|}
\hline & $\begin{array}{l}\text { Monthly } \\
\text { Profits }\end{array}$ & $\begin{array}{l}\text { Truncated } \\
\text { Profits (99th) }\end{array}$ & $\begin{array}{c}\text { Truncated } \\
\text { Profits (95th) } \\
\end{array}$ & $\begin{array}{l}\text { Log } \\
\text { Profits }\end{array}$ & $\begin{array}{l}\text { Monthly } \\
\text { Sales }\end{array}$ & $\begin{array}{l}\text { Truncated } \\
\text { Sales (99th) }\end{array}$ & $\begin{array}{l}\text { Log } \\
\text { Sales }\end{array}$ & $\begin{array}{c}\text { Number of } \\
\text { Paid Workers }\end{array}$ & $\begin{array}{l}\text { Recruited a } \\
\text { New worker }\end{array}$ & $\begin{array}{c}\text { Log } \\
\text { Capital Stock } \\
\end{array}$ \\
\hline \multicolumn{11}{|l|}{ Full effect (Upper bound) } \\
\hline Registered with the D.S. & $\begin{array}{l}13,706^{*} \\
(8,241)\end{array}$ & $\begin{array}{l}10,834 \\
(6,847)\end{array}$ & $\begin{array}{c}5,923 \\
(4,774)\end{array}$ & $\begin{array}{l}0.357^{*} \\
(0.202)\end{array}$ & $\begin{array}{l}122,295 \\
(85,196)\end{array}$ & $\begin{array}{c}99,073 \\
(72,440)\end{array}$ & $\begin{array}{c}0.460 \\
(0.319)\end{array}$ & $\begin{array}{c}0.525 \\
(0.426)\end{array}$ & $\begin{array}{c}0.102 \\
(0.0902)\end{array}$ & $\begin{array}{c}0.396 \\
(0.258)\end{array}$ \\
\hline \multicolumn{11}{|c|}{ Effect after controlling for log capital stock (lower bound) } \\
\hline Registered with the D.S. & $\begin{array}{c}8,996 \\
(8,074)\end{array}$ & $\begin{array}{c}7,054 \\
(6,474)\end{array}$ & $\begin{array}{c}2,544 \\
(4,462)\end{array}$ & $\begin{array}{c}0.168 \\
(0.187)\end{array}$ & $\begin{array}{c}61,868 \\
(85,602)\end{array}$ & $\begin{array}{c}44,438 \\
(71,944)\end{array}$ & $\begin{array}{c}0.174 \\
(0.298)\end{array}$ & $\begin{array}{c}0.431 \\
(0.437)\end{array}$ & $\begin{array}{c}0.106 \\
(0.0925)\end{array}$ & n.a. \\
\hline Number of Observations & 2,181 & 2,181 & 2,181 & 2,123 & 2,139 & 2,139 & 2,088 & 1,017 & 1,017 & 1009 \\
\hline Mean for control group in sample & 30537 & 28662 & 25048 & 9.87 & 237185 & 211399 & 11.42 & 2.35 & 0.36 & 12.278 \\
\hline
\end{tabular}

Notes:

Registration with the D.S. instrumented with offer of the 10,000 Rs, 20,000 Rs, or 40,000 Rs registration treatments.

Information only treatment group excluded from these regressions.

All regressions include controls for randomization strata and for the baseline value of the dependent variable.

Robust standard errors in parentheses, clustered at the firm level, ${ }^{*}, * *$, and ${ }^{* * *}$ indicate significance at the 10,5 and 1 percent significance levels respectively. 
Table 5b: Effect of formalizing on different channels

\begin{tabular}{|c|c|c|c|c|c|c|c|}
\hline & $\begin{array}{l}\text { Paid } \\
\text { Taxes }\end{array}$ & $\begin{array}{l}\text { Amount of } \\
\text { Taxes paid }\end{array}$ & $\begin{array}{c}\text { Formal } \\
\text { Accounting }\end{array}$ & $\begin{array}{c}\text { Has } \\
\text { Receipt book }\end{array}$ & $\begin{array}{l}\text { Business } \\
\text { Bank A/c. }\end{array}$ & $\begin{array}{c}\text { Applied for } \\
\text { Business Loan }\end{array}$ & $\begin{array}{c}\text { Applied for } \\
\text { Personal Loan }\end{array}$ \\
\hline \multirow[t]{2}{*}{ Registered with the D.S. } & -0.0643 & $-8,865$ & -0.103 & $0.352 * * *$ & 0.0239 & -0.00421 & -0.0451 \\
\hline & $(0.142)$ & $(6,670)$ & $(0.0763)$ & $(0.130)$ & $(0.0812)$ & $(0.0770)$ & $(0.0690)$ \\
\hline Lag included & No & No & Yes & No & Yes & No & No \\
\hline Observations & 1,036 & 1,036 & 1,016 & 1,049 & 1,059 & 1,059 & 724 \\
\hline Survey rounds question asked & $\mathrm{R} 2, \mathrm{R} 3, \mathrm{R} 4$ & $\mathrm{R} 2, \mathrm{R} 3, \mathrm{R} 4$ & R1-R4 & $\mathrm{R} 2, \mathrm{R} 3, \mathrm{R} 4$ & R1-R4 & $\mathrm{R} 2, \mathrm{R} 3, \mathrm{R} 4$ & $\mathrm{R} 2, \mathrm{R} 3$ \\
\hline \multirow[t]{2}{*}{ Mean for control group in sample } & 0.66 & 6800 & 0.141 & 0.31 & 0.14 & 0.10 & 0.056 \\
\hline & $\begin{array}{c}\text { Share of } \\
\text { Sales made } \\
\text { to Govt. (\%) }\end{array}$ & $\begin{array}{c}\text { Electric } \\
\text { Connection } \\
\text { in Bus. Name }\end{array}$ & $\begin{array}{c}\text { Applied for } \\
\text { Govt. } \\
\text { Contract }\end{array}$ & $\begin{array}{l}\text { Participate } \\
\text { in Govt. } \\
\text { SME program }\end{array}$ & $\begin{array}{l}\text { Advertised } \\
\text { in Last six } \\
\text { Months }\end{array}$ & $\begin{array}{c}\text { Business has } \\
\text { clear and } \\
\text { visible sign }\end{array}$ & $\begin{array}{l}\text { Changed } \\
\text { Location }\end{array}$ \\
\hline Registered with the D.S. & $\begin{array}{c}3.543 \\
(2.285)\end{array}$ & $\begin{array}{l}-0.152 \\
(0.116)\end{array}$ & $\begin{array}{l}0.000453 \\
(0.0540)\end{array}$ & $\begin{array}{c}0.0535 \\
(0.0449)\end{array}$ & $\begin{array}{l}0.261^{* * *} \\
(0.0892)\end{array}$ & $\begin{array}{l}-0.0895 \\
(0.130)\end{array}$ & $\begin{array}{l}-0.0504 \\
(0.0870)\end{array}$ \\
\hline Lag included & No & No & No & No & Yes & Yes & No \\
\hline Observations & 1,020 & 724 & 724 & 724 & 1,036 & 1,030 & 1,016 \\
\hline Survey rounds question asked & $\mathrm{R} 2, \mathrm{R} 3, \mathrm{R} 4$ & $\mathrm{R} 2, \mathrm{R} 3, \mathrm{R} 4$ & $\mathrm{R} 2, \mathrm{R} 3$ & $\mathrm{R} 2, \mathrm{R} 3$ & R1-R4 & R1-R4 & $\mathrm{R} 2, \mathrm{R} 3, \mathrm{R} 4$ \\
\hline Mean for control group in sample & 0.96 & 0.40 & 0.022 & 0.033 & 0.16 & 0.56 & 0.18 \\
\hline
\end{tabular}

Notes:

Registration with the D.S. instrumented with offer of the $10,000 \mathrm{Rs}, 20,000 \mathrm{Rs}$, or 40,000 Rs registration treatments. Information only treatment group excluded from these regressions.

All regressions include controls for randomization strata, and for the lagged dependent variable if it was collected. Robust standard errors in parentheses, clustered at the firm level.

$*, * *$, and ${ }^{* * *}$ indicate significance at the 10,5 and 1 percent significance levels respectively. 


\begin{tabular}{|c|c|c|c|c|c|c|c|c|c|}
\hline & $\begin{array}{c}\text { Trust in } \\
\text { Provincial } \\
\text { Government }\end{array}$ & $\begin{array}{c}\text { Trust in } \\
\text { Municipal } \\
\text { Government }\end{array}$ & $\begin{array}{c}\text { Trust in } \\
\text { National } \\
\text { Government }\end{array}$ & $\begin{array}{l}\text { Trust in } \\
\text { the courts }\end{array}$ & $\begin{array}{c}\text { Trust in the } \\
\text { Police }\end{array}$ & $\begin{array}{l}\text { Confident in } \\
\text { police } \& \text { courts } \\
\text { to settle } \\
\text { bus. dispute }\end{array}$ & $\begin{array}{c}\text { Agrees } \\
\text { being good } \\
\text { citizen means } \\
\text { paying taxes }\end{array}$ & $\begin{array}{l}\text { Thinks } \\
\text { Govt. charges } \\
\text { business } \\
\text { too much tax }\end{array}$ & $\begin{array}{c}\text { Feels Govt. } \\
\text { spends revenue } \\
\text { on important } \\
\text { items }\end{array}$ \\
\hline Registered with the D.S. & $\begin{array}{c}0.634^{* * *} \\
(0.234)\end{array}$ & $\begin{array}{c}0.559 * * \\
(0.234)\end{array}$ & $\begin{array}{c}0.227 \\
(0.221)\end{array}$ & $\begin{array}{l}-0.0387 \\
(0.188)\end{array}$ & $\begin{array}{c}-0.0993 \\
(0.238)\end{array}$ & $\begin{array}{c}0.0267 \\
(0.203)\end{array}$ & $\begin{array}{c}0.511^{* * *} \\
(0.188)\end{array}$ & $\begin{array}{l}0.517^{* *} \\
(0.238)\end{array}$ & $\begin{array}{l}-0.0410 \\
(0.232)\end{array}$ \\
\hline Lag included & Yes & Yes & Yes & Yes & Yes & No & No & No & No \\
\hline Observations & 369 & 369 & 369 & 369 & 369 & 369 & 369 & 369 & 369 \\
\hline Mean for control group & 0.360 & 0.310 & 0.620 & 0.811 & 0.567 & 0.744 & 0.767 & 0.444 & 0.378 \\
\hline
\end{tabular}

Notes:

Registration with the D.S. instrumented with offer of the $10,000 \mathrm{Rs}, 20,000 \mathrm{Rs}$, or 40,000 Rs registration treatments.

Information only treatment group excluded from these regressions.

All regressions include controls for randomization strata, and for the lagged dependent variable if it was collected.

Robust standard errors in parentheses $*, * *$, and $* * *$ indicate significance at the 10,5 and 1 percent significance levels respectively. 


\section{Appendices for Online Publication Only}

\section{Appendix 1: What was the registration process like for the firms registering during our intervention?}

The firms which registered as a result of our intervention were given a brief survey at the time of payment of their treatment amount in order to collect some details of their experience registering. Appendix Table 1 summarizes some of the key details of the registration process. The first point to note is that there was a big difference in practice between the process of registration in Colombo, and that in Kandy. In Colombo four of the five DSs had been centralized to the Provincial Council level and the process of registration was very efficient. Firm owners in Colombo were generally not asked to provide any documents at the time of registration other than their national identity card. They were also able to pay 1000 LKR instead of the usual 500 LKR registration fee and get their business registration certificate in one day. Many firms chose to do this. We see in Colombo 85 percent of firms registering classified the process as very easy, with the registration process typically involving a total of 2 days and 2 visits to the DS.

In contrast, the procedure for registering was more burdensome in Kandy, where the DS office generally required the firm owner to provide three documents in addition to their national identity card: a Grama Sevaka certificate from their local G.N. (the smallest local administrative area) testifying that the business existed; proof of being licensed at the Pradeshiya Saba or Municipal council level; and, if their business was operated on a property they did not own, a letter from the property owner indicating no objection to business registration. These other documents typically required 3 to 4 days to obtain and involved fees of 385 to 1300 LKR for the Pradeshiya Saba or Municipal council license, and in some cases, 500-1000 LKR for the letter from the property owner. The DS itself then took longer to process the registration. There was an average of 8 days between the time all of the necessary documents were submitted and BRC was issued. We asked firm owners to tell us when they had submitted the paperwork to the DS, so our payments to them were not denied if delays occurred at the DS. Thus even in Kandy it was easily feasible to register within the time window given to firms. Nevertheless, 26 percent of firms who registered in Kandy described the process as not that easy, or as very difficult. 
Appendix Table 1: The Registration Process for those registering

\begin{tabular}{lcc}
\hline & \multicolumn{2}{c}{ Percent } \\
& Colombo & Kandy \\
\hline Had to provide the following: & 11.1 & 95.7 \\
Grama Sevaka certificate & 0.0 & 100.0 \\
Pradeshiya Saba or Municipal License & 0.0 & 4.3 \\
Public Health Inspection Report & 3.7 & 0.0 \\
Environmental Authority Report & 3.7 & 0.0 \\
Wildlife Conservation Department Report & 0.0 & 4.3 \\
Certificate of Technical Skills & 11.1 & 95.7 \\
Letter from property owner showing no objection & & \\
Classify the registration process as: & 85 & 17 \\
Very Easy & 15 & 57 \\
Somewhat easy & 0 & 26 \\
Not that easy or very difficult & & \\
& & \\
Total number of visits to institutions & 2.11 & 5.9 \\
Mean & 2 & 5 \\
Median & 2.4 & 8.1 \\
Number of Days at D.S. between submission and receipt of BRC & 6 \\
Mean & 2 & 4.2 \\
Median & 0.3 & 3 \\
Number of Days getting other documents processed & 0 & \\
Mean & & \\
Median & & \\
\hline
\end{tabular}

Appendix Table 2: Treatment doesn't affect which firms survive

\begin{tabular}{|c|c|c|c|c|c|c|}
\hline & $\begin{array}{c}\text { Treatment } \\
\text { Group } 1 \\
\end{array}$ & $\begin{array}{c}\text { Treatment } \\
\text { Group } 2 \\
\end{array}$ & $\begin{array}{c}\text { Treatment } \\
\text { Group } 3 \\
\end{array}$ & $\begin{array}{c}\text { Treatment } \\
\text { Group } 4\end{array}$ & Control & $\begin{array}{c}\text { F-test of equality } \\
\text { p-value }\end{array}$ \\
\hline Retail & 0.21 & 0.20 & 0.22 & 0.24 & 0.24 & 0.960 \\
\hline Manufacturing & 0.36 & 0.33 & 0.35 & 0.32 & 0.36 & 0.972 \\
\hline Services & 0.43 & 0.48 & 0.43 & 0.44 & 0.40 & 0.913 \\
\hline Colombo & 0.48 & 0.50 & 0.46 & 0.53 & 0.48 & 0.926 \\
\hline More than 2 paid workers & 0.56 & 0.57 & 0.58 & 0.57 & 0.55 & 0.994 \\
\hline Says would register and sees benefit to doing so & 0.48 & 0.47 & 0.51 & 0.48 & 0.46 & 0.979 \\
\hline Sales in last month at Baseline & 217562 & 147252 & 185649 & 165991 & 183185 & 0.634 \\
\hline Doesn't keep records & 0.48 & 0.58 & 0.54 & 0.59 & 0.52 & 0.613 \\
\hline Years of Education of Owner & 10.97 & 10.48 & 10.82 & 11.38 & 10.52 & 0.125 \\
\hline Number of Paid employees & 2.89 & 3.21 & 3.10 & 3.02 & 3.04 & 0.866 \\
\hline Registered at the Pradeshiya Saba & 0.71 & 0.63 & 0.72 & 0.67 & 0.62 & 0.507 \\
\hline Profits in last month at Baseline & 30176 & 27919 & 32851 & 33460 & 31220 & 0.589 \\
\hline
\end{tabular}

Note: Treatment Group 1 is the information and reimbursement only group, Groups 2, 3 and 4 were offered 10,000 Rs, 20,000 Rs,

and 40,000 Rs respectively. 
Appendix Table 3: Round by Round results for impact of being registered on firm profits

\begin{tabular}{|c|c|c|c|}
\hline & $\begin{array}{l}\text { Monthly } \\
\text { Profits }\end{array}$ & $\begin{array}{c}\text { Truncated } \\
\text { Profits (99th) }\end{array}$ & $\begin{array}{c}\text { Log } \\
\text { Profits }\end{array}$ \\
\hline Impact in Round 2 survey & 14,792 & 6,967 & $0.550^{*}$ \\
\hline (average 15 months post treatment) & $(18,077)$ & $(11,452)$ & $(0.324)$ \\
\hline Impact in Round 3 survey & $16,049 *$ & 13,918 & $0.437^{*}$ \\
\hline (average 22 months post treatment) & $(9,272)$ & $(8,733)$ & $(0.240)$ \\
\hline Impact in Round 4 survey & 12,328 & 10,688 & 0.304 \\
\hline (average 31 months post treatment) & $(10,382)$ & $(9,399)$ & $(0.286)$ \\
\hline P-value for testing equality of impacts across rounds & 0.9264 & 0.9565 & 0.9829 \\
\hline
\end{tabular}

Notes:

Registration with the D.S. instrumented with offer of the $10,000 \mathrm{Rs}, 20,000 \mathrm{Rs}$, or 40,000 Rs registration treatments. Information only treatment group excluded from these regressions.

All regressions include controls for randomization strata and for the baseline value of the dependent variable. Robust standard errors in parentheses, clustered at the firm level.

$*, * *$, and $* * *$ indicate significance at the 10,5 and 1 percent significance levels respectively.

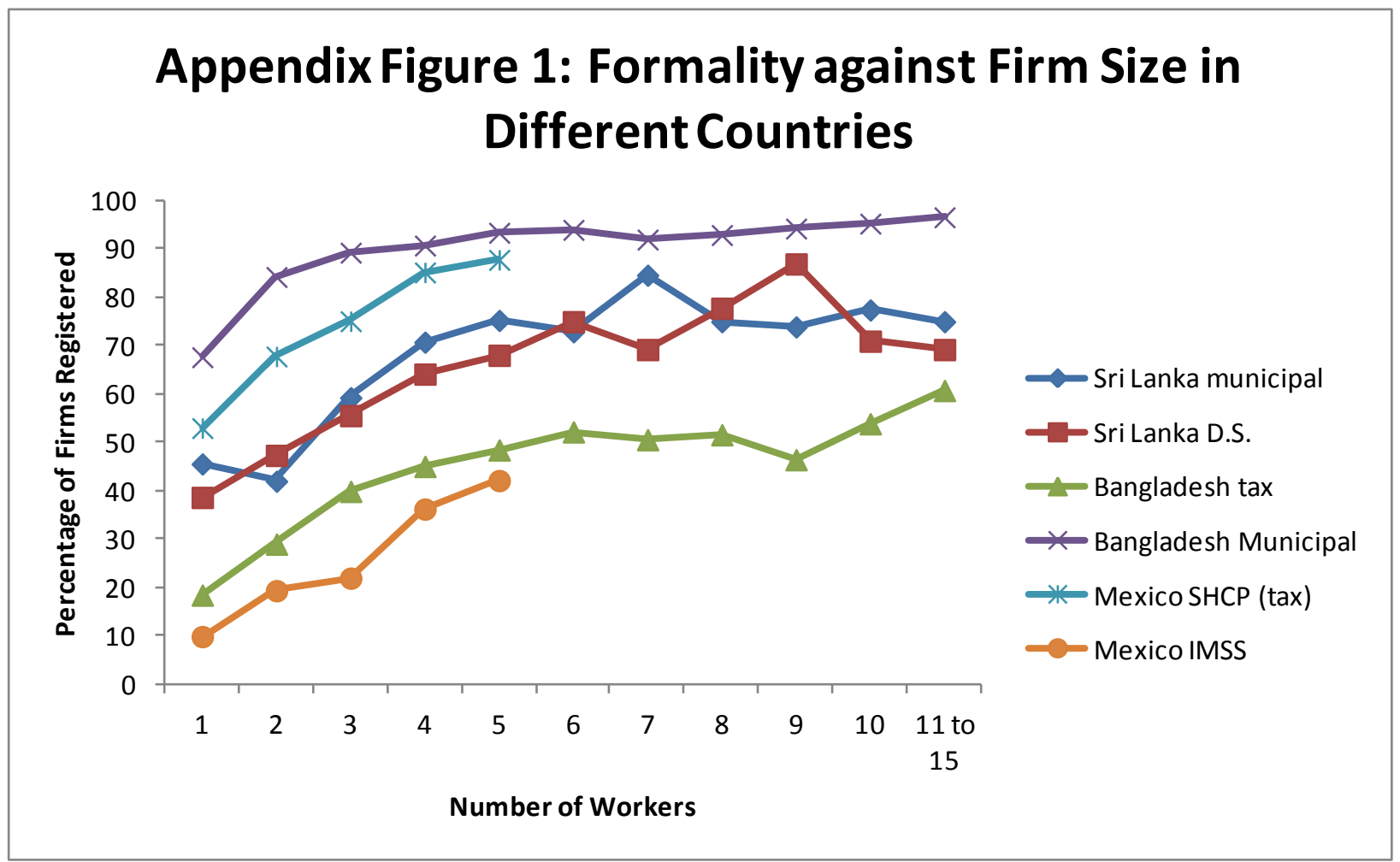

